
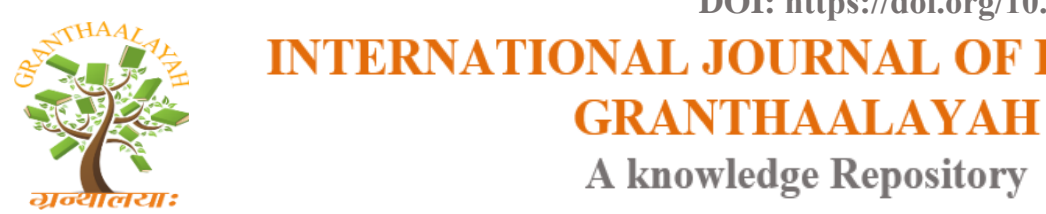

Social

\title{
OCCUPATIONAL STRESS OF PROFESSORS IN BRAZIL
}

\author{
Daysi Farias ${ }^{1}$, Paulo Lourenço Domingues Jr ${ }^{2}$, Albertina Silva ${ }^{3}$ \\ ${ }^{1,3}$ Instituto Federal do Rio de Janeiro Brazil \\ ${ }^{2}$ Universidade Federal Rural do Rio de Janeiro (UFRRJ), Brazil
}

\begin{abstract}
Occupational stress and quality of working life (QWL) are the subjects approached in this research work. Occupational stress represents an intervening factor in work relations and life quality of professors in a higher-education federal network of the state of Rio de Janeiro, Brazil. Thus, the research proposes to analyze the relation between occupational stress and QWL of highereducation professors, identifying its impacts, following Cooper's and Vilas Boas and Morin's approaches. This is a qualitative and exploratory research. A semi-structured interview was performed for data collection, with the participation of 34 professors, located in three campi, divided between the baixada and south of Rio de Janeiro. The selected professors work for more than two years in the federal network. The selected technique for data treatment was content analysis. There was the confirmation of stressful factors in work relations and their impact in the professors' life quality, subject of this research. There were found work leaves due to physical and mental diseases, change of campus, discharge of functions and the institute. In the narratives it was perceived how much suffering the professors demonstrated, almost a calling for help and they hope a public management takes care of the human resources, just as they manage the material resources. Other sources of pressure and dimensions were shown, which leads to reflect about the continuity of the research with the professors, to contribute to the strategies that balance the indicators affecting the professor's health, and assessed in this research, in order to minimize this situation.
\end{abstract}

Keywords: QWL; Occupational Stress; Higher Education Professors.

Cite This Article: Daysi Farias, Paulo Lourenço Domingues Jr, and Albertina Silva. (2019). "OCCUPATIONAL STRESS OF PROFESSORS IN BRAZIL." International Journal of Research - Granthaalayah, 7(10), 94-103. 10.29121/granthaalayah.v7.i10.2019.379.

\section{Introduction}

Since the Industrial Revolution in the early $20^{\text {th }}$ century, the organizations went through transformations aiming to increase productivity, bring maximum efficiency in the execution of tasks, and think about the worker's satisfaction. According to Rodrigues (1994, p. 20), "in this period there are the first movements and structured, systemized applications inside the organization, using the quality of working life - QWL". According to the author, the organizations 
aimed to increase the results through limited resources, causing changes in commercial aspects and production. Thus, by changing the form of production, indirectly the strategy of handling with people was reshaped.

In this context, "the human capital starts to be understood as a fundamental strategy to face the radical transformations" (GIL, 2008, p. 39). However, in the core of this step there are the workers, whose adaptation to this new context was not linear nor salutary. Therefore, in order to increase productivity, the performance of tasks that implicated new and better results was due to economic issues, and the worker did not possess the knowledge about the role performed in the process of development and growth of the organizations.

Paraphrasing Couto (COUTO,1987 apud BCHECHE; KILIMINIK, p. 101, 2015), "the main factors of pressure that affect the individual in the work are related to the urgency of the activities imposed and the bad time management, associated to a series of exigencies". To comprehend the causes of these work pressures, the research developed aims to understand the causes, the factors and the tensions that workers suffer in their work environment.

To investigate this field of knowledge, the present research was structured based on the following methods: Vilas Boas and Morin's (2014) Quality of Working Life and the researches of Walton (1973, 1980, 1985), Hackman and Oldham (1975), Boisvert (1977), Nadler and Lawler (1983), Levine, Taylor and Davis (1984), Huse and Cummings (1985) and contemporary researches as: Fernandes (1996), Limongi França (1996, 2007, 2009, 2012), Sampaio (2004, Sant' Anna and Kilimnik (2011), and occupational stress in the studies and model of Cooper et al (1976, 1982, 1988, 2011), Karasek (1979), Lazarus e Folkman (1984), Rossi (2009), Zanelli (2010), Zille (2010, 2011), Lipp (2012), Limongi França, Rodrigues and Kanakidan (2012). This division is due to the understanding that there could be a descriptive approach of each of these aspects, according the theories that approach these subjects.

In the 70's, the researcher Walton (1973) conceived the expression "life quality", which according to him was used to describe certain environmental and human values neglected until then by the industrial societies. Because of the technologic, productive and economic development, there was the workers' exploitation, who was lead to the top of physical exhaustion, having as consequence the state of fatigue. From that time in Brazil, there was an unbridled search for the quality of production quality and improvement in results. The companies aimed the excellence of quality, which according to Fernandes (1996, p. 22) was "understood as the tendency to constant improvement and form of work organization, having the goal of continuous improvement of the productive process".

From this point of view, it is understood that the organizations aim for professionals who adapt to the exigencies of the contemporary working world and to the competitive market. Therefore, the QWL conquers space as an aspect inherent to the process of competitiveness, allied to the worker's well-being in the institution (LIMONGI-FRANÇA, 2007).

Thus, the guiding question of the research is: how does occupational stress affect the QWL from the professors' point of view in a federal network of higher education in Rio de Janeiro? 
According to Vilas Boas and Morin (2015), understanding the QWL and the impacts that lead to the professor's malaise is a challenge, but it brings benefits to workers and society.

Therefore, the research considered, besides answering to the proposed objective, conceive strategies - in the management of this education federal network, especially in the higher education

- that increase the knowledge about this worker's health and his/her insertion in this work organization.

\section{Method}

The research was performed in Rio de Janeiro Federal Institute in four campi. They were chosen for offering under graduation courses. The procedures of data collection of the interviews followed the following criteria: sending e-mails to the directors of the education institution; waiting for the directors' acceptation; scheduling day and time of the interviews, in which there were the higher number of professionals in the campus. The choice for professors also met the following criteria selection: gender, different ages, with children or without children, experience in higher education. The filter of time was also considered, contemplating the exercise of the function for more than five years, even outside the federal network. The campus location-Baixada Fluminense and South Fluminense, and the teaching time in higher education completed the data. Thirty-four interviews were performed. The professors chose the places of the interviews, where they felt more "protected". A script was elaborated following the models that grounded the study performance. The Content Analysis (CA) was used in order to assess data found in the answers, treating and interpreting them according to the models and theories that guided the research foundation. Some criteria were respected, such as "exhaustiveness (complete assessment of the text); homogeneity (separation between subjects to be studied); the objectivity (coding results); and the adequacy (to the objectives of the study). Therefore, data were separated in categories in order to have the maximum clarity and precision. The campi and subjects of the research received codes respecting the consent form.

\section{Data Collection}

Two questionnaires were applied to the professors: one regarding the demographic and professional survey with 10 questions and other with 16 discursive semi-structured questions, following the script proposed by the models of Vilas Boas and Morin (2014) and Cooper et al (1988). The interviews were performed in the campi where the professors worked during the research. All interviewed professors followed the work regime of 40 working hours per week, with exclusive dedication.

The contact with these professors was made through work colleagues in common. However, it does not mean that there was an immediate accept to answer the interview questions.

The Vilas Boas and Morin's (2014) systemic approach of QWL highlights the factors (characteristics, relations, charge, hours and safety in work) and indicators (meaning of the work and in the work, well-being and psychologic suffering, stress related to work, commitment, presence, work and life balance). The Occupational Stress Approach of Cooper et al (1988) 
indicates the factors intrinsic to work, the role of the organization and the relations with work, career, structure and organizational environment.

Because of the complexity of the studies about QWL and Occupational Stress, it is suggested that future researches could also observe the work organization, the leadership, and studies that focus on the worker's health.

\section{Characterization of the Subjects of the Research}

\section{Campus 1 - South Fluminense}

Seven professors were interviewed. All male, $14.28 \%$ are single and $85.78 \%$ are married; they have between 1 and 4 children, and are in average 40 years old. The average of academic experience is 8 years. As for the qualification and titles, 4 are doctors and 3 have a master's degree.

For the professors of this campus, there are elements registered in their narratives that compromise QWL according to Vilas Boas and Morin's model: excess of bureaucracy, work overload, conflicts, lack of materials to execute work, pressure, deadlines, distant workplace, unhealthy and bad environments, inadequate planning, physical environment, relationships, among others, as shown by the professors' speeches. According to a professor's statement:

A factor that compromises QWL is the lack of materials and the intern structure that can prevent you from doing your work. This work is very important. A simple example: "I arrived in the classroom and the laboratory machines had no access to the network." This is irritating. There is an IT technician that prepares the place for the teacher and when he does not perform his job, it disturbs mine. (E6:C1).

\section{Campus 2 - South Fluminense}

Nine professors participated in the interview, 55.56\% are female and $44.44 \%$ are male; 6 are married, 2 are divorced and 1 is single. Age range is in average 42 years. They have between 1 and 2 children. They have academic experience of 14 years in average, of which 6 years in average in the institute. Regarding the professors' qualification and titles, there are 4 doctors and 5 masters.

The interviewees affirm that the stress indicators are pressure due to deadlines and publications. They refer to the time to the task performances:

We live with a lot of pressure - deadlines, articles, researches; it is very complicated. This makes the relationships bad. In my case there is the aggravating factor of distance. We miss family, children (pause). I miss spending more time with my family (pause). That is why I demand so much of myself when performing tasks with quality. As I do not have my family around, I work. (E8:C2).

\section{Campus 3 - Baixada Fluminense}

There was a number of $50 \%$ of women and $50 \%$ of men; 12 were married, 3 were single and 3 were divorced. The age range was around 40 years old. As for the titles and academic qualification, 10 are masters and 8 are doctors. In average, the interviewees have 14 years of professional experience, of which 8 years were in the institute. All professors have exclusive dedication of 40 hours per week. 
In this campus, it stands out that the distribution of workload is one of the biggest indicators of stress and it causes the reduction of life quality.

For me, what impairs life quality is the lack of balanced schedule distribution. Here we have cases of professors who have a large workload and those who do not. Lack of planning. I see that many coordinators are amateurs. I myself had many times a workload larger than those of my colleagues. This disturbs my life. I am very tired. (E23:C3).

They also highlighted that having a technic management surrounded by elements that constitute the effective management would reduce the occupational stress.

The management would be a variable that would disturb the quality of working life. Not the personification of this management, but the way it is organized to do things, with no planning. I even think that here it is cultural to do things without planning. (E30:C3).

These speeches confirm that QWL is impaired by the structure of the professor's work, for example, the speeches about schedule distribution and lack of planning, as well as the conflicts in relationship that come from this lack of structure, according to the base of the QWL General Model (MORIN, 2008) and the Systemic Approach of QWL (VILAS BOAS; MORIN, 2017).

However, there are evidences that the biggest causes of stress are related to the physic, psychologic, mental and hormonal components that occur when an individual needs adaptation (LIPP, 2012). "When stress is triggered, it can cause diseases (silence) as I already said, the determinant thing is to perform my work, with no difficulties. Without anybody who makes it difficult or disturbs it". (E2:C1).

Performing tasks is something that does not bother them, but not having autonomy, placed by a manager who is a leader and favors interpersonal relations in work relations.

The statement of the professors in this campus is relevant as well as the other campi. The lack of work organization is a factor that generates a stressful environment, directly affecting the work performance and life quality of this worker. To them "Some kind of disorganization that leads to work overload. Unplanned tasks, lack of material and resources. Having people intruding where they are not supposed to nor is this their job." (E3:C1). These are aspects that must be considered to reflect on the management from the point of view of possibilities for adaptation and changes.

Relationship problems are associated with a QWL factor that refers to the characteristics of work relations. Therefore, the speeches demonstrate that this QWL factor affects the stress indicator related to work. Lack of headship access can also be considered a structural problem.

I entered the institute along with other professor. I delivered my documents, however they did not accept my master's degree. I do not know if it was due to the public notice, or something else, I did not get it but he did. He received it. I do not know how. I was treated differently. This part makes me really sad. (Pause). Does it stress me? I do not know, but it makes me really sad. I think it stressed me before. Now I say it does not matter, I need my job to supplement my income. If not, I would have left. Now, I would rather not to think about this. I am like this (pause) financial. 
I have made a lot of effort, I have the qualification, nothing could stop me. I should be rewarded for this. This makes me really sad. Very much. (E10:C2).

These narratives demonstrate that there are traces of an inadequate management for the kind of work performed in the institution, as well as the commitment of work and personal life relations.

\section{Results and Discussions with The Approaches: Qwl And Occupational Stress}

The results and discussions came from the treatment of data following the QWL approaches of Morin and Villas Boas (2016) and Cooper et al (1988).

Even though we perceive that men are more objective in the answers, the suffering and perspective of change is present with no gender distinction.

Some professors were suspicious when talking about subjects related to organization, especially regarding management. With the interviews, it is clear how much the professor suffers and does not have support and/or a safe place, they feel alone. In the social perspective, there is almost a distance between the human being and the professor. The professor must play a character and act according to the scenario. In the organizational perspective, they are subjected to the rules, bureaucracy, to the coercive and psychologic power and to the compliance of a contract. In a human perspective, the man shows, intense, tense and potent. Being in a classroom is more than a profession, it is a mission.

According to the results of the interviews, there was a sense of compromising and commitment in labor activities. Being a professor is not being a myth or immortal, but a man who builds, who performs a role and a bond between dreams and accomplishments, who involves emotions and responsibilities along with the students. However, this struggle is solitary in some moments and there is a lot of suffering, constantly among a precarious work. They did not report a concern from the management to understand the dimensions, meeting these perspectives. Even the man or the woman who claims to be immune to these stressful factors, when answering the questions that required confirming this immunity, surrendered and realized that they were "masking" their answer.

The professors reported an environment of occupational disease when speaking about the other campi and managements, they cried or blamed themselves for not reaching out of the situation of vulnerability they were in. Sometimes because they were in a probative situation, and sometimes because they did not know what is a public organization, among other factors that discouraged their attitude, their identity, their pride and even their knowledge. What calls attention the most is that in no campus was there a work of survey and monitoring of these factors, these work leaves, powering the stress. It is impressive that because they suffer alone, they do not know that there are other colleagues who are going through the same situation. That causes conflicts with colleagues, headships and management technicians.

It was observed that there are still factors and indicators that directly affect the professors' wellbeing and personal life, even for those who work in the South Fluminense, a place known for lower violence rates, low traffic, country life, which was understood as a better life quality. Many of 
those who are located in the South Fluminense are not from there. That distances them from their family and causes changes, resulting in the distance from their homes, friends, spaces and territories. Some even thought about exoneration for this reason. But they remember their economic needs and reduced possibilities because of age and effort, making them impotent to act.

In this research there is also no difference of gender when it comes to suffering at work. Both men and women cried, made similar statements of exclusion, with the same behavior, that is, both were alone and did not want contact, they asked for work leaves in case they did not get the change of campus. The pain does not choose a gender. The common sense that men are more rational and the women are more emotional is not true when it comes to psychologic suffering.

\section{Considerations}

The performance of this work resulted in the reflection of the components of QWL created by the authors, and applicability of Morin's (2008) initial approach developed by Vilas Boas e Morin (2015, 2016, 2017). The study highlighted that some aspects identified deserve deeper studies, such as: leadership, depression, sadness, fear, among others, which values the importance to continue studying QWL with professors.

In Cooper, Cooper e Eaker's (1988) approach, the following sources of pressure were confirmed, intrinsic to work: role of the organization, the relations, career, structure and organizational environment. However, other sources were identified, such as: violence in the environment, the leadership issue and consequences of stress on sexuality, among others that were not studied by the authors, and that lead professors to search for the help of a specialist in health. Some needed prescription medication and to others some alternative therapies were indicated. Even finding other factors, indicators and elements presented by the authors (COOPER et al 1988; VILLAS BOAS; MORIN 2014), there was no commitment of the approaches. However, the research showed other sources of pressure that could lead to the professor's sickening. This study suggests that through data analysis, there is the possibility of increasing components of occupational stress.

Finally, it stands out that professors recognize the relation between stress and QWL. Some work leaves, due to psychologic diseases, change of campus or conflicts in relationships came from the lack of QWL and a high level of stress.

It was noticed that some professors idealized that when applying for the position in a federal institution, they would be in "heaven", and that problems such as lack of infrastructure, air conditioning, lack of work organization, violence inside the campus and around it would be unacceptable. However, many cases occurred in this level and affected many professors, making them wish to apply for a new position. According to a professor "to me, suffering this kind of violence in many environments was a reality check, I did not expect to be mugged inside the campus. Today I need to think well not to abandon everything. I am living a nightmare".

Therefore, the broadening of the studies is proposed in other campi and federal institutions. Going against the grain of a politic logic and creating an organizational model that meets or reduces the occupational stress and improves QWL requires a more detailed analysis of each campus in its formation, occupation and objective of action. 
The goal of this research is, therefore, to contribute to new researches that look inside the organizations and see that the talent is performed with people and by people.

\section{References}

[1] CHAUÍ, M. Escritos sobre a universidade. São Paulo: Editora UNESP, 2001.

[2] COOPER, L. C. The stress check: coping with the stress of life and work. 1981. Prentice-Hall, INC., Englewood Cliffs, N.J. 07632.

[3] COOPER, L. C. Presenteeism is more costly than absenteeism. HR Journal. Apr. 20, 2011. Disponível em

<http://www.hrmagazine.co.uk/hro/features/1019355/presenteeism-costlyabsenteeism>. Acesso: nov.2017.

[4] COOPER, L. C; CARTWRIGHT, S. An intervention strategy for workplace stress. Journal Psychosomatic Research, v. 43, n. 1, pp. 7-16, 1997. Disponível em:

<http://www.jpsychores.com/article/S0022-3999(96)00392-3/abstract>.

[5] COOPER, L. C; CARTWRIGHT, S. Theories of organizational stress. Oxford University Press, $1^{\circ}$ edition, january, 7, 1999.

[6] COOPER, L.C.; COOPER, R.; EAKER, L. Living with stress. Londres: Penguin Books, 1988.

[7] COOPER, L.C.; LUNDBERG, U. The science of occupational health. E-book. Canada: Edition Wiley-Blackwell, 2010.

[8] COOPER, C. L; MARSHALL, J. Occupational sources of stress: a review of the literature relating to coronary heart disease and mental ill health. Journal of Occupational Psychology. v. 49. n. 1. 1976. Disponível em: http://onlinelibrary.wiley.com/doi/10.1111/j.2044-8325.1976.tb00325.x/epdf. Acesso: jun/2016.

[9] FERNANDES, E.C; GUTIERREZ, L.H. Qualidade de vida no trabalho (QVT) uma experiência brasileira. São Paulo: Revista de Administração, v. 23, n.4. outubro/dezembro, 1988. p 29-38. Disponível em: <http://www.spell.org.br/documentos/ver/18906/qualidade-de-vida-no-trabalho-qvt--uma-experiencia-brasileira.> Acesso: out. 2016.

[10] HACKMAN, J. R; OLDHAM, G. R. Development of the Job Diagnostic Survey. Journal of Applied Psychology, v. 60, n. 2, 1975, p. 159-170. Disponível em:

<http://www.jwalkonline.org/upload/pdf/Hackman\%20\%26\%20Oldham\%20(1975)\%20\%20Development\%20of\%20the\%20JDS.pdf.> Acesso em: nov. 2016.

[11] KARASEK JR, R. A. Job demands, job decision latitude, and mental strain: implications for job redesign. Administrative Science Quarterly, v. 24, n. 2, Jun., 1979, p. 285-308 Disponível em: http://sci-hub.cc/10.2307/2392498. Acesso: nov. 2016.

[12] KILIMNIK, Z. M. et. al. et al. O atual estado da arte da qualidade de vida no trabalho no Brasil. Anais do XVIII Encontro Nacional dos Programas de Pós-Graduação em Administração. Curitiba/PR: Anpad, 1994, p. 305-325. In. SANT'ANA et al. (org). Qualidade de Vida no Trabalho: abordagens e fundamentos. Rio de Janeiro: Elsevier; Belo Horizonte, MG: Fundação Dom Cabral, 2011.

[13] LAZARUS, R. S.; FOLKAMN, S. Coping Theory and Research: past, present, and future. Psychosomatic Medicine, v. 55, 1993, p. 234-47. Disponível em: <http://www.emotionalcompetency.com/papers/coping\%20research.pdf>. Acesso: jun.2016.

[14] LIMONGI-FRANÇA, A. C.; KANIKADAN, A. Y. S. A construção de um instrumento de coleta de dados a partir do modelo de indicadores Biopsicossocial e organizacional: BPSO-96 e do modelo de competência do bem-estar - BEO, sobre a gestão de qualidade de vida no trabalho. REAd. edição 54, v. 12, n. 6 nov-dez 2006. Disponível em: http://www.seer.ufrgs.br/index.php/read/article/view/40282/25618. Acesso: out. 2016.

[15] LIPP, M. N (org). O stress do professor. 7 ed. Campinas, SP: Papirus, 2012. 
[16] LUNDBERG, U; COOPER, C. L. The Science of Occupational Health. UK Copyright Library of Congress Cataloging-in-Publication Data. Ebook. 2016. Disponível em:

<https://secure.livrariacultura.com.br/secure/minha-conta/meus ebooks?_requestid=7716937>. Acesso: fev. 2017.

[17] MEYER, J.P.; ALLEN, N.J. A three-component conceptualizacion of organizational comitment. Human Resource Management Review, v. 1, n.1, 1991. Disponível em: <https://www.sciencedirect.com/science/article/pii/105348229190011Z>. Acesso: set. 2017.

[18] MORIN, E. Os sentidos do trabalho. Tradução: Ângelo Soares, Professor de Comportamento Organizacional da Université du Québec à Montréal (UQAM). RAE. Revista de Administração de Empresas: São Paulo, v. 41, n. 3, p. 8-19, jul/set, 2001. Disponível em: <http://www.scielo.br/pdf/rae/v41n3/v41n3a02.pdf.> Acesso: 04 fev. 2017.

[19] MORIN, E; TONELLI, M. J; PLIOPAS, A. L. V. et al. Os sentidos do trabalho: implicações pessoais e organizacionais, 2007a. In: SANT'ANNA, A. S. et al. (org). Qualidade de Vida no trabalho: abordagens e fundamentos. Rio de Janeiro: Elsevier; Belo Horizonte, MG: Fundação Dom Cabral, 2011. 3a reimp.

[20] MORIN, E. M. Sens du travail, santé mentale au travail et engagement organisationnel, Études et recherches - Rapport R-543 (avec la collaboration de ARANHA, F. - FGV-EASP). Montréal: IRSST. 2008, 62p. Disponível em: <http://www.irsst.qc.ca/media/documents/PubIRSST/R- 543.pdf >. Acesso em: set/2017.

[21] MORIN, E; TONELli, M. J; PLIOPAS, A. L. V. Sens du travail, Santé mentale au travail et engagement organisationnel. Ėtudes et recherches, Rapport R-543, IRSST. In: Vilas Boas, A. A. e MORIN, E. M. Indicadores de qualidade de vida no trabalho para professores de instituições públicas de ensino superior: comparação entre Brasil e Canadá. Contextus. Revista Contemporânea de Economia e Gestão. v.14, n. 2, abr/jun 2016. Disponível em:

<http://www.contextus.ufc.br/2014/index.php/contextus/article/view/830>. Acesso: dez.2016.

[22] O'DRISCOLL, M. P. \& COOPER, C. L. Coping with work-related stress: A critique of existing measures and proposal for an alternative methodology. Journal of Occupational and Organizational Psychology, v. 67, 1994. p. 343-354 Disponível em: <http://sci-hub.cc/10.1111/j.2044-8325.1994.tb00572.x> Acesso: set. 2016.

[23] ROBERTSON, I. T; COOPER, C. L; WILLIANS, J. The validity of the occupational stress indicator. International Journal of Work, Health \& Organizations, v. 4, n. 1, 1990, p. 29-39. Disponível em: <http://sci-hub.cc/10.1080/02678379008256962.> Acesso: jun. 2016.

[24] TARDIF, Maurice e LESSARD, Claude. O trabalho docente: elementos para uma teoria da docência como profissão de interações humanas. Tradução de João Batista Kreuch. 5. ed. Petrópolis, RJ: Vozes, 2011.

[25] VILAS BOAS, A. A.; MORIN, E. M. Fatores de Qualidade de Vida no Trabalho em Universidades Públicas: Uma Comparação entre Brasil e Canadá. Anais do $14^{\circ}$ Congresso de Stress da ISMA (Internacional Stress Management Association) e do $16^{\circ}$ Fórum de Qualidade de Vida no Trabalho, Porto Alegre, RG, Brasil, 2014. Disponível em:

$<$ http://www.spell.org.br/documentos/ver/43024/indicadores-de-qualidade-de-vida-no-trabalhopara-professores-de-instituicoes-publicas-de-ensino-superior--uma-comparacao-entre-brasil-ecanada-- >. Acesso: set/2017.

[26] VILAS BOAS, A. A; MORIN, E. M. Sentido do Trabalho e Fatores de Qualidade de Vida no Trabalho para Professores de Universidades Públicas do Brasil e do Canadá. Anais do Encontro Nacional da Associação Nacional de Pós- graduação e Pesquisa em Administração, Rio de Janeiro, RJ, Brasil, 38, Set. 2014a. Disponível em: <http://www.anpad.org.br/admin/pdf/2014_EnANPAD_GPR227.pdf>. Acesso: set/2017.

[27] VILAS BOAS, A. A.; MORIN, E. M. La Qualité de Vie au Travail des professeurs des établissements publics d'enseignement supérieur: une comparaison entre le Brésil et le Canada. Rapport de Recherche de post-doctorale, HEC, Montreal, Canadá, 2014b. 119 p. Disponível em: 
<https://www.researchgate.net/publication/256446873_Le_sens_du_travail_et_la_qualite_de_vie _au_travail_dans_les_etablissements_publics_d'enseignement_superieur_une_comparaison_entre _le_Bresil_et_le_Canada>. Acesso: set/2017.

[28] VILAS BOAS, A. A.; MORIN, E. M. Stress no Trabalho, Bem-Estar Psicológico e Comprometimento com o Trabalho: efeito e relações com a qualidade de vida no trabalho. In ROSSI, A. M. et al (Org) Stress e Qualidade de Vida no Trabalho: stress interpessoal e ocupacional, São Paulo: Atlas, 2015.

[29] VILAS BOAS, A. A.; MORIN, E. M. Indicadores de qualidade de vida no trabalho para professores de instituições públicas de Ensino Superior: uma comparação entre Brasil e Canadá. Contextus. Revista Contemporânea de Economia e Gestão. v. 14, n. 2. abr/jul 2016. Disponível em: <http://www.contextus.ufc.br/2014/index.php/contextus/article/view/830.> Acesso: nov. 2016.

[30] VILAS BOAS, A. A.; MORIN, E. M. Qualidade de vida no trabalho: um modelo sistêmico de análise. São Paulo: Revista Administração em Diálogo, 2017. Disponível em: <http://www.spell.org.br/documentos/ver/45626/qualidade-de-vida-no-trabalho--um-modelosistemico-de-analise>. Acesso: nov. 2017.

[31] WALTON, R. E. Quality of working live: what is it? Sloan Management Review, v. 15, n. 1, 1973. Disponível em: <https://s3.amazonaws.com/academia.edu.documents/29949855/quality_of_working_life_maza heri_\%28_msg00021.pdf?AWSAccessKeyId=AKIAIWOWYYGZ2Y53UL3A\&Expires=152033 1655\&Signature=lonlfPUBECCmmtdNC8xMMrEF\%2F\%2Bs\%3D\&response-contentdisposition=inline\%3B\%20filename\%3DQuality_of_working_life_what_is_it.pdf>. Acesso: abr. 2016.

[32] ZANELLI, J. C. (Cord.) Estresse nas organizações de trabalho: compreensão e intervenção baseadas em evidências. Porto Alegre: Artmed, 2010.

[33] ZILLE, L.; ZILLE, C; BRAGA, C. Estresse ocupacional: como os gestores brasileiros estão respondendo às transformações na função gerencial?. In: SANT'ANNA, A. S; KILIMNIK, Z. M. (org). Qualidade de vida no trabalho: abordagens e fundamentos. Rio de Janeiro: Elsevier; Belo Horizonte, MG: Fundação Dom Cabral, 2011.

*Corresponding author.

E-mail address: daysi.farias@ ifrj.edu.br/pldomingues@ ig.com.br/albertina.sousa@ uol.com.br 